\title{
The People's or the World's: RMB Internationalisation in Longer Historic Perspective
}

\author{
Niv Horesh \\ School of Humanities and Languages, University of Western Sydney, Sydney, NSW 2751, Australia \\ Correspondence should be addressed to Niv Horesh, n.horesh@uws.edu.au \\ Received 29 June 2011; Accepted 18 August 2011 \\ Academic Editor: Richard C. K. Burdekin \\ Copyright () 2011 Niv Horesh. This is an open access article distributed under the Creative Commons Attribution License, which \\ permits unrestricted use, distribution, and reproduction in any medium, provided the original work is properly cited. \\ Prognoses of China's currency-Renminbi or RMB in short—going global have become a hotly debated topic in the economic and \\ popular literature of late. While some analysts are tipping a gradual transformation of the RMB into the world's next principal \\ reserve currency in lieu of the US\$, others contend that the deficiencies of China's financial market will continue to preclude any \\ such transformation for a long time to come. The aim of this paper is to survey the arguments put forward by either camp and to \\ weigh into this debate not only through the prism of applied economic theory or political economy but also through the prism of \\ economic history.
}

\section{Introduction}

The need to approach the issue of RMB internationalisation from fresh perspectives may perhaps be partly vindicated by what Wu et al. identify as the inevitable "paucity" of empirical analyses [1]. Equally compelling, however, is the fact that much of what has already been written on this issue is predicated on the fairly recent historic experience of the onset of the pound sterling and US\$ through the 20th century, and on the still more recent experience of the Euro in the early 21 st century. (See, e.g., Hefeker and Nabor [2].) Implicitly, therefore, the prospects of RMB internationalisation are assessed based on indicators of convergence between the Chinese economy at present, and the British, American, Japanese, or EU economies in recent decades. But such an analytical framework, when removed from the broader historic context, might of itself rule out a more distinct Chinese path to global economic eminence-one where, for example, the depth of domestic capital markets might not turn out to be a critical determinant of RMB internationalisation as was the case in the Anglo-American development trajectory.

The following historic survey can perhaps shed light on current debates about the future role of RMB in at least one way: they remind us that the prospect of Chinese currency used as international currency may not be entirely new. For even though traditionally cast Chinese copper coinage was swept aside by Western steam-powered minting technology in the late 19th century, it had for a millennium or so prior set the benchmark for East and Southeast Asian monetization. As China was phasing out traditional copper coinageknown as caixa or "cash" to Europeans-Chinese indentured labourers were still taking it with them aboard British ships sailing across the South Pacific to serve as token currency for gambling and grocery purposes [3].

The analysis offered below explores what might inspire a geopolitical rally around, and popular trust in, the RMB as alternative reserve currency in the near future. It aims to revisit the degree to which the well-known and widely discussed imperfections of China's domestic capital markets could hinder currency internationalisation. Reliable currency is conventionally understood here as primarily a "store of value," "unit of account" and "medium of exchange" (for a classical theoretical discussion, see, e.g., Von Mises [4]).

In this context, economists such as Wu, Pan, and Wang seem to suggest that "highly developed and open capital markets in the home economy, where foreign investors can freely trade the currency-denominated financial instruments and generate profit," is one of eight important requisites that an "aspirant" international reserve currency must satisfy [1]. The other five important requisites to consider would be 
China's perceived geo-political clout, its credit-worthiness, and the relative size of its economy; the ability of foreigners to obtain and convert RMB notes on demand; low domestic inflation and low exchange rate volatility; lack of administrative or legal barriers to RMB cross-border mobility. Yet, because they accord great significance to the depth of capital markets-precisely as the Anglo-American experience would warrant-Wu, Pan, and Wang conclude that "[i]t is probably too optimistic...to expect the RMB to become a global currency before 2025" [1].

\section{The Historicity of Chinese Currency as Global Currency}

Economic historians might, on their part, not wish to exclusively ponder "China's rise" as a 21 st-century strategic actuality, and also draw insights from China's preponderance in the premodern global economy going as far back as antiquity. Notably, whilst hybrid Sino-Hellenistic copper coins from the CE 1st century were excavated in Xinjiang, no pre-modern Chinese (or Indian) coins were ever found in Western Europe. Similarly, many Sassanid-Iranian (CE 224651) and some contemporaneous Byzantine gold coins were found much further east near Huhehot in Inner Mongolia as well as in Northwest China, but only few Chinese coins of that period were found west of the Tarim Basin. The Sassanids imported Chinese porcelain en masse and seemed to have paid these off with bullion; there is little evidence of significant backflow of Chinese coins to Iran before the Song era $[5,6]$. Conversely, Roman coins of the Republican period were widely excavated in India but not in China proper, even though Chinese silk was a luxury commodity imported to Rome through the Silk Road [7-10] (small quantities of North Indian coins minted in the 9th-10th centuries were discovered in the USSR west of the Urals. See, [11]).

In light of these findings, it seems that scholars should strive to better demarcate the supply of various currencies and of currency substitution across pre-modern Eurasia. Suffice it to note here that, in excavations of Xiongnu tombs in present-day Mongolia, for example, golden jewelry from the West was found alongside Chinese silk and copper coins, but Hellenistic coinage of that era was nowhere to be seen. In sites as faraway east as the Feng Sufu Tombs (Beipiao, Liaoning) glassware of Roman origin was found dating back to 5 th century CE, yet even in a site of that later era there was no evidence of Roman coinage [12].

It would appear that the great breakthrough of Chinese copper coinage beyond China proper occurred during the cosmopolitan Tang period (CE 618-907). At that period, Chinese coinage had served as a model for Japan's first indigenous currencies and was sought after for the first time in many parts of North and Southeast Asia where standardised media of exchange were scarcer. Subsequently, Chinese copper coinage of the Song dynasty (CE 960-1279) was even current in some parts of South India possibly through trade links with Southeast Asia. Song coinage had become so popular that it could serve as the currency of choice-either through import or local emulation-in many parts of Southeast
Asia. Such coinage thus supplanted by the 13th century CE Java's original currency system, which had been predicated as early as 8-9th centuries CE on South-Indian-inspired silver-gold weights [13]. Moreover, in the mid-12th century, Japan imported large amounts of Chinese copper coins, even though it was more abundant in copper than China, and certainly not bereft by then of coin production metallurgic knowhow [14].

Chinese pre-modern copper coinage reached the apex of its global presence around the 14th century by which time it had been circulating widely in Japan, Korea, Annam, and along the coastal trading hubs of Cambodia, Thailand, and Burma. It was also rapidly gaining popularity in Java and parts of Sumatra, the north Philippines, and Borneo at much the same time. To a lesser extent, Chinese coins could be found along India's Malabar and Coromandel coasts, and in Ceylon between the 7 th-14th centuries $[13,15]$. The earliest Chinese copper coins found in Sri Lanka appear to date back to the 9th century CE, whilst some of the Chinese coins found in South India date back to 7 th century CE. The famous tributary missions, on which the Yongle Emperor sent eunuch Zheng He (CE 1371-1453), even brought Chinese copper coinage to Mainland East Africa, whilst on Zanzibar Chinese coins may have been first used as early as the 7 th century CE $[16,17]$.

It was only in 1636 and 1678, respectively, that the Tokugawa shogunate in Japan, and Choson Korea, were able to fully supplant Chinese copper coins with their own copper coinage [18-20]. In fact, when the Dutch arrived in Southeast Asia in the 17th century, they found that Chinese copper coinage had been so popular there that they began importing copper coinage directly from China. Such coins were in high demand in, for example, less-monetized Annam, and sold there in return for Annamese raw silk. The Dutch then sold the silk in Japan in return for locally mined silver, which could fetch enormous profits when sold in China [13].

The Dutch attempted to introduce their own silver colonial coinage (dubbeltjes) in Java, but these did not take root. Therefore, until the 18th century, they relied on the local Chinese community for a supply of picis - the Javanese term for locally cast Chinese-style coinage. It was only in 1724 that the Dutch felt confident enough to reintroduce a European-style copper coin (duiten or doits). The production of picis was discontinued as late as 1763 , by which time the main high-denomination regional currency was SpanishAmerican silver dollars (a.k.a peso, piece-of-eight, or Carolus dollar); Dutch gold stuiver coins never gained the upper hand locally [21].

\section{The Origins of Monetary Globalization and Residual Divergence}

The discovery of abundant silver deposits in Latin America (16th century) reconfigured the pre-modern Eurasian monetary system, ushering in the first thrust of globalization [22]. On the one hand, this newfound source of silver reinforced the West's comparative advantage in precious-metal supply, and, on the other hand-it made possible the creation of 
a truly global currency (the Spanish-American silver dollar) for which the Chinese were willing to sell ever-greater quantities of tea and silk [23].

Latin-American silver discoveries dovetailed with Ming China's (CE 1368-1644) sharp reduction of mining and coin production, and its growing reliance on external supply of high-denomination currency in the form of silver [24-26]. To be sure, the Qing dynasty (1644-1912 CE) revitalised annual coin production almost to the same peak level recorded during the Song five centuries earlier. But China's monetary system had become acutely reliant on imported silver by then, either in coin or ingot form. Silver mainly served as merchants' higher-denomination currency and was by far the preferred means of tax payment, even though its purity and authenticity were assayed privately for the most part. For reasons that are still not entirely clear, neither the Ming nor Qing polities opted to enhance domestic silver mine production or introduce silver coinage, right until the late 19th century when European minting technology was universalised [23, 27].

Archaeological findings confirm that, at least since early modern times, specie (in dollar denominations) flowed from West to East in return for commodities such as silk and tea. At the same time, Chinese copper cash flowed from East to Southeast Asia in return for tropical produce. Economic historians, therefore, might provocatively observe that there is nothing entirely new in the way that modern China is furnishing the US with manufactured goods in return for US\$ derivatives, whilst pushing for its own currency zone in Asia (see below). Granted, the reasons behind the undervaluation of the RMB against Western currencies nowadays, which renders Chinese goods so attractive overseas, and the reasons why Western silver currencies were at a premium in early-modern China owe to entirely different sets of circumstances; more importantly, since the collapse of the Bretton Woods accords in the mid-1970s, the US\$ can no longer be counted as specie substitute. Yet there does seem to be some uncanny resonance between the early modern global monetary system and the contemporary one in that China's net trade surplus with the West is largely funded by US Treasury bonds, which are denominated in an international currency still called dollar.

It is otherwise still not entirely clear why base metals such as copper played a much more limited monetary role in premodern West Asia and Europe compared with East Asia. Perhaps the only exception to this pattern was Japan where, as of the 17th century, copper coinage was supplemented with gold and silver coinage on the back of vigorous domestic mining expansion [28]. In early Medieval Europe silver coinage was predominant of course, whilst in Byzantium and the Islamic world both gold and silver flans were used to strike coins. As coins were smelted and often transported from one contiguous currency zone to another, the premodern world was devoid of a truly global currency circulating across all zones until the advent of the Spanish-American dollars.

That no single currency circulated right across Eurasia until early modern times was not only a result of the preference for copper in the East or the relative abundance of silver in the West but also the path-dependent monetary structures that obtained in either region. These structures determined, amongst other prescripts, the production technology used and the modes of coin supply regulation. Hence, Chinese pre-modern coins of various eras all evince minimalist inscriptions, whilst European coinage was largely minted or struck with elaborate imagery; in pre-modern Europe "free coinage" was commonly tolerated, whereas in China coinage and mining were strictly seen as state prerogative [29].

Echoing the "oriental despotism" paradigm prevailing in Europe around his time, Max Weber famously posited that the Chinese preference for base-metal coinage had been designed to allow emperors greater opportunity to extract seignorage than was possible in Europe [30]. More recently, however, economic historian Akinobu Kuroda has noted that, in fact, Chinese copper coinage had perforce lower intrinsic value per unit of production and thus afforded lower seignorage potential than was the case in Europe. Drawing on decades of meticulous comparative study of East Asian currencies, Kuroda's important insight might also explain why in comparative terms, European feudal lords and West Asian sultans debased the composition of their coinage in pursuit of greater seignorage revenue more often than could be tolerated in Chinese statecraft. There, the provision of copper coinage came to be seen, in the first instance, as a corollary of the Confucian imperial duty to "alleviate the needs of the people" (bianmin) rather than a means to generate imperial revenue [31, 32].

Whilst subsidiary copper coinage had been issued in Republican Rome, the metal subsequently played a minor role in Europe's disparate monetary systems and remained rarely coined in much of the medieval period. It was only in the 16th century that alloy coinage containing copper spread all over Europe as token currency (billon) but was almost from the outset subject to heavy debasement (on billon, see [33]). Notably, banknotes had been invented in China as early as the 11th century but came into use in Europe only in the 17th century. It is arguably this temporal divide which might help explain the different paths by which Chinese emperors and European overlords resorted to enhance seignorage The Mongol Yuan dynast not only relied on banknote issuance, but also radically reduced coin production precisely because it was deemed unprofitable to the throne. By fiat, therefore, less coin was required in China per se, and so large quantities flowed over the course of the 14th century to Southeast Asia where such standardized media of exchange were at a premium. Additionally, high-denomination note issuance made silver ingots less sought after in China, arguably resulting in outflow of the metal to Europe via West Asia over the course of the 14th century [34].

In China, therefore, copper cash was less readily debased than European coinage, whilst banknotes-mostly denominated in strings of 1,000 coins-were ultimately issued without adequate metallic reserve; Chinese imperially issued banknotes lost favour among the populace by the 15th century precisely because they were overprinted in order to enhance state revenue [31]. Initially, Europe's experience with banknotes was uneven to say the least, but a sounder reserve policy eventually took root in England in the 19th century as part of the emergence of the early modern national debt 
economy, so much so that, with the suspension of the gold standard in the 1930s, European banknotes were no longer fiduciary but wholly fiat (i.e., not partially convertible into bullion), a situation obtaining formally today in most countries of the world following the collapse of Bretton Woods.

Indeed, the 19th century was a time when money incrementally shed its universal metallic anchorage with the transition to territorial currencies bound to nation states and central banks' "legal tender." However, due to political instability and civil war, China was not to have an effective single "legal tender" until 1935. From the mid- nineteenth century to 1949 , successive imperial Chinese governments, warlord regimes, and semi-official banks had issued various types of paper currency with an uneven record of success. In addition, private money shop scrip, remittance drafts, military wage coupons, product certificates, and later even underground Chinese Communist Party (CCP) paper currency were circulating in different parts of the country concurrently [35].

As China ventured into economic modernity in the early twentieth century, silver dollars, subsidiary coins, and banknotes gradually superseded its late-Imperial bimetallic standard. But, for the next three decades, the leaders of the newly established Republic were unable to enforce monetary unification on breakaway provinces. An ephemeral turnaround appeared in sight only in late 1935, when an invigorated KMT (Kuomintang or "Nationalist") administration took China's currency off the silver standard and proclaimed its first fiat currency in the modern era, the fabi. In the leadup to the fabi reform, a large number of regional banks still operated outside of the central government's reach. More often than not, these banks had been amenable to warlords, who did not hesitate to milk the local civilian population through what economists call an "inflation tax." In other words, many regional banks serviced warlord debt with proceeds obtained from banknote disbursement. Still others strove to fend off the unification thrust of the KMT government by maintaining a stable regional currency and securing banknote convertibility to bullion [35].

The KMT government's intention to trim its large budget deficit helped muster support for the 1935 move off silver. A modest budget surplus, a higher degree of monetary integration and some improvement in productivity were achieved during 1936-1937. However, in the final analysis, unchecked military spending incurred by anti-Communist campaigns and the impending war with Japan did not leave the fabi, much chance of retaining its credibility. In 1948, an eleventhhour attempt to nominally repeg China's Nationalist currency to gold failed, unleashing hyperinflation and irreversibly tainting the KMT's reputation in economic management [36]. Today's talk of RMB as future global currency should therefore be placed against the backdrop of China's acute monetary fragmentation in the century or so leading up to the proclamation of the RMB.

Evident throughout both the early modern and modern phases in the evolution of Chinese currency is that having any form of currency widely accepted is contingent upon the degree of popular trust in its "store-of-value" and "exchange- medium" properties. Indeed, the pound sterling's supplanting by the US\$ around the mid-20th century and the reasons why the Renminbi is perceived at present as challenging the US\$ viability as global reserve currency may both owe to geopolitical shifts in confidence. And despite the absence of equally detailed records from the 11th century, circumstantial evidence would indicate that much of Southeast Asia had transitioned from Indian-style coinage to Chinese-style coinage at least in part because of a shift in confidence vis-à-vis Northern-Song China (CE 960-1127), which was engendered in turn by the latter's reputation as an exporter by-default of reliable currency and as a powerhouse of economic advancement at the time and by its expanding trade links in the region [37]. Yet, the stature of Chinesegovernment-cast coinage as international currency went into steep decline through the remaining late-imperial era, reaching a low-water mark of popular confidence in the Republican period. Precisely how the RMB managed to restore faith in Chinese-government-issued currency therefore needs to be closely examined in the next section.

\section{The Evolution of RMB in the Era of Central Planning}

In the summer of 1947, the People's Liberation Army (PLA) was consolidating its advance across North and Eastern China, bringing territorial integrity under Chinese Communist Party rule to many parts of the country. Soon afterwards, trade links between areas previously cut off by civil war were reestablished. But often the currencies used across contiguous areas remained discrete; exchange rates between local currencies proved volatile through the civil war, greatly hampering economic recovery. Carrying over from the lateImperial and Republican eras, this monetary fragmentation impinged on the momentum gained by PLA ground forces and brought to the fore the need to urgently unify China's currency. From then on, monetary unification became one of the most potent propaganda messages drummed up by the Communists, who were well aware of the deep-seated popular disenchantment with KMT monetary reforms in the 1940s.

As the area under Communist control expanded, the CCP leadership therefore had to turn its mind to macro-economic planning. Later in 1947, it proposed to unify China's disparate currency systems and to work toward a centralised mechanism of banknote issuance. To that end, Dong Biwu was appointed Chairman of the Economic Bureau of North China and entrusted with promoting a new "people's" currency-the RMB. Thereafter, currency unification measures progressed incrementally with local cadres and Dong occasionally publishing official exchange rates between the RMB and currencies issued by erstwhile authorities. Concomitantly, Dong launched an extensive campaign to rally grass-root support for the RMB. These concerted efforts led to the establishment of the People's Bank of China (PBC) as a bank singularly in charge of money supply on behalf of the advancing Communist forces. Gradually, the note issue prerogatives enjoyed by foreign banks operating on Chinese 
soil were rescinded, followed by a Communist crackdown on Chinese bank prerogatives, but disparate currencies issued by the Communist themselves in different parts of the country continued to circulate side by side for another year or so [38].

On December 1, 1948, the People's Bank of China was formally established in Shijiazhuang, Hebei Province, that is, well before the proclamation of the People's Republic of China itself. On the eve of its establishment, there had been a plethora of currencies circulating side by side in recently "liberated" areas, namely, areas taken over by the Communists from retreating Nationalist forces. The main Communist currencies at the time had been notes issued by affiliate regional institutions: the Farmers' Bank of Northwest China; the Bank of Southern Hebei, the Bank of Beihai, Zhongzhou Farmers bank, and the Bank of the Northeast. Over the course of 1949 most of these banknotes had been redeemed in return for new $\mathrm{RMB}$ notes at a rate of between 100 and 2000 units of older currency to 1 RMB [39].

At the same time, the PBC also enforced measures to strictly regulate China's privately run financial institutions, and constrain foreign bank's ability to transact local business. Most KMT-controlled semi-official banks were dissolved, as was the KMT central bank. Nonetheless, the two largest of these banks were merely reorganised, and their prewar name remains in effect up to the present: the Bank of China and the Bank of Communications. Smaller privately-run banks and family-run "money shops" (qianzhuang) were similarly reorganised under CCP oversight or dissolved [40].

These measures were all carried out with a view toward nominating the PBC as an all-powerful monobank within a few years. To that end, the PBC was allowed to go beyond traditional central bank roles and provide credit to retail and corporate clients, who were not suspected of KMT sympathies and formed China's shrinking and anxious private sector. Indeed, many such individuals and corporations were experiencing liquidity problems as the economy was gradually transitioning to central planning and collective ownership [41-44].

As China emerged from the great destruction of the civil war with a newly proclaimed national currency, severe inflationary pressures came to bear on the real value of the RMB in the early 1950s. These problems were allegedly compounded by the nominally high units of value of nonCCP currencies still unofficially circulating in some regions, by large quantities of forged notes disseminated by Japanese and later KMT special forces, and by intermittent food shortages (on Japanese forgeries, see, e.g., [45]; on alleged KMT forgeries, see, e.g., [46]). To make matters worse, the official exchange rate between $\mathrm{RMB}$ and older currencies often proved confusing because of the different denominations used and due to the low quality of RMB note printing as compared with some of the older currencies, which had been more resistant to wear and tear (on the evolution of RMB units, see PBC official data at: http://www.pbc.gov.cn/ publish/huobijinyinju/387/1590/15901_.html).

In light of these problems, the CCP decided to embark on a second currency unification campaign. As of March 1955 , the PBC exerted greater efforts to curb money supply

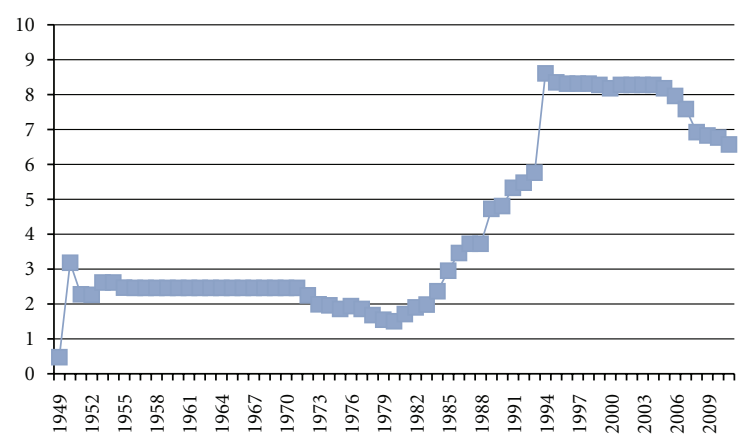

Figure 1: US\$ to RMB official exchange rate, 1949-2010.

and improve RMB note quality, whereby older RMB notes were converted to new ones at a rate of $1: 10,000$. From 1955 to the present, newly redenominated RMB remained legal tender. Concomitantly, the PRC set up in the mid1950s highly centralised monetary oversight mechanisms. By the late 1950s, all banks had been merged into the PBC producing a monobank financial system. Under this system, the $\mathrm{PBC}$ wielded not only central bank administrative powers but also commercial banking functions; through cash-flow audits, tight credit overhaul and fiscal restraint on the part of the government, the PBC was eventually able to achieve price and money-supply stability and vest all monetary powers firmly in the hands of the state $[43,44]$.

RMB nominal foreign exchange rates during China's monobank era point to two primary development phases before the country opened up to foreign investment: 19551972 and 1973-1979. The first phase parallels the Bretton Woods accords, whereby Western currencies had been pegged to the US\$ at a fixed rate. During, those earlier phases the RMB, too, was convertible into US\$ at a fixed rate of 2.46 to US\$ 1 (see Figure 1). In practice, however, the RMB was not tradable at all; its availability overseas was dictated by state-controlled trade without any correlation with market demand. During the later phase of 1973-1979, the Bretton Woods system collapsed, and Western countries successively went on a floating exchange rate; the PRC therefore decided to notionally adjust the RMB exchange rate based on the value of a basket of currencies, while at the same time aiming to maintain continuity by occasionally revaluing the $\mathrm{RMB}$ [47].

\section{The Makeover of RMB in the Reform Era}

With Mao Zedong's death in 1976, the CCP slowly moved to relax central planning. In 1979, Deng Xiaoping prevailed over Maoist hard liners to embark on a bolder set of economic reforms that came to be known as the Open-Door Policy (gaige kaifang). The reforms started off by allowing greater freedom to peasant household to retain surpluses above the production quotas set by the state and to semicollectively operate township and village and enterprises (TVEs). But the focus of policy makers quickly shifted to urban industries, where foreign direct investment in special economic zones was promoted. In the latter part of 
1979, the PBC, too, embarked on monetary reform, whereby retail credit and deposit functions were localised, and the monobank system relaxed. By 1983 China's State Council declared formally that the PBC was to eventually assume only central bank responsibilities and withdraw from mercantile banking activity (the wording of this 1983 declaration as published in the CCP organ, the People's Daily (Renmin ribao) can be viewed at: http://www.people.com.cn/item/flfgk/ gwyfg/1983/112203198306.html).

As a result, the PBC relinquished control of many branches across the country to focus on exercising monetary coordination in pursuit of macroeconomic growth objectives. In order to bolster export manufacturing, in 1981 the RMB was at first devalued in state-controlled foreign trade transactions vis-à-vis the official exchange rate. But, in other transactions such as remittances from overseas Chinese to family members on the Mainland, the basket-of-currencies peg was still applied. This two-tier approach accentuated China's cheap-labour advantages, while ensuring other contact between PRC and foreign nationals remained on an even keel (i.e., RMB purchasing power in terms of other currencies was not eroded across the board).

To be sure, this two-tier approach remained in effect until 1985 despite criticism from a number of countries as being unfair. But in 1985, the PRC stopped publishing the favourable exchange rates applied to foreign trade (maoyi neibu) and nominally returned to single-sheet exchange rates. These single-sheet rates were nominal because, in effect, the two-tier system was kept unofficially, giving rise to a black market where both Chinese and foreign individuals in possession of foreign currencies aimed to convert their funds underboard, often through trade-licensed companies, for a more favourable exchange rate. During that period, the PRC devalued the RMB single-sheet exchange rate time and gain. In 1985 US\$ 1 was worth 2.95 RMB, but by 1993 it was worth 5.76 RMB (see Figure 1), a measure which clearly boosted China's exports and buildup of inbound FDI.

The next milestone in the evolution of the RMB dates back to 28 December 1993 when the State Council promulgated its intention of reforming the exchange rate mechanism. Aware of the malignant spread of a black market, the PRC undertook to genuinely strive for convergence between official and unofficial exchange rates. After an adjustment period, it was foreshadowed that the exchange rate would move into a partially floating mode along a band and that a Chinese intrabank market for foreign-currency reserves would be established (the 1993 official pronouncement to that effect can be viewed at: http://www.pbc.gov.cn/ publish/bangongting/91/1590/15900/15900_.html).

The impact of the new policy was felt by tourists the following year: as part of the two-tier rationale, foreign visitors had, since the early 1980s, had to purchase goods within China at designated venues by using RMB-denominated Foreign Exchange Certificates (FECs). Slightly smaller than RMB notes in design, these certificates were valued in practise above par, partly so as to promote tourist spending on local goods and services and to curb imports. Conversely, Chinese nationals requiring foreign currency for travel abroad were subject to at-par exchange rates and to strict individual quotas; expatriate residents wanting to remit their salaries overseas also had to register with authorities. But, as of 1994, preferential-rate FECs were abolished following a drastic devaluation of the RMB official exchange rate. Foreigners were expected from then on to purchase RMB at local banks at the same exchange rate that Chinese individuals and firms would convert their foreign currency [48-50].

China's financial market reform gained further momentum as its first two bourses were inaugurated in 1991. More and more foreign banks were otherwise allowed to set up branches in China during the 1990s, although most could provide retail services in local currency only from the mid2000s onwards. Gradually, more and more export businesses were allowed to switch from compulsory handover of foreign-currency revenue to voluntary conversion, thereby allowing greater liquidity of foreign assets in the interbank market. Arguably, the thrust toward internationalization of the RMB was held back by the Asian Financial Crisis of 1997-1999, when the dangers posed by free capital flows to emerging economies became apparent. Yet, as Liew and other scholars noted, although the value of other Asian currencies was plummeting during the crisis, China sought in the main to responsibly stabilise the region rather than further devalue its currency in a bid to maintain the competitiveness of its export industries ([51], see also [47, 52]). Ultimately, the Asian Financial Crisis also called into question the desirability of individual Asian countries maintaining a US\$-peg when the great bulk of their trade is intraregional in nature, as Ogawa has persuasively argued [53].

Today, despite the accretion of massive foreign currency reserves over more than three decades of export-led economic reform, China may still seem a long way away from a full floatation of the RMB in world financial markets. The $\mathrm{RMB}$ does not meet what are widely seen as basic requisites to do with internationalization in terms of financial market openness. As Chen and Cheung have shown, although the use of the RMB in trade financing overseas has increased rapidly in recent years; China still maintains strict capital controls, which render its financial system quite insular from global money markets. However, even Chen and Cheung acknowledge that the RMB "has great potential to become an international currency" and that its acceptance in the global economy is affected by both economic and political factors [54].

China has not yet reached the stage of unhindered capital account convertibility. On the other hand, China nowadays enforces greater current-account transparency and has been, since 2007, progressively grooming Hong Kong as an "offshore" clearing house for the nascent global trade in RMBdenominated financial assets. Last year, the sanctioning of trade in RMB per se was announced in Hong Kong [55].

Concomitantly, the offshore RMB market has been growing steadily. Due to the US dollar shortage effect on trade experienced during the recent global financial crisis, the People's Bank of China initiated a scheme to allow settlement of all types of cross-border trade in RMB. In January 2011, China trialled for the first time RMB trading even in the USA [56]. 


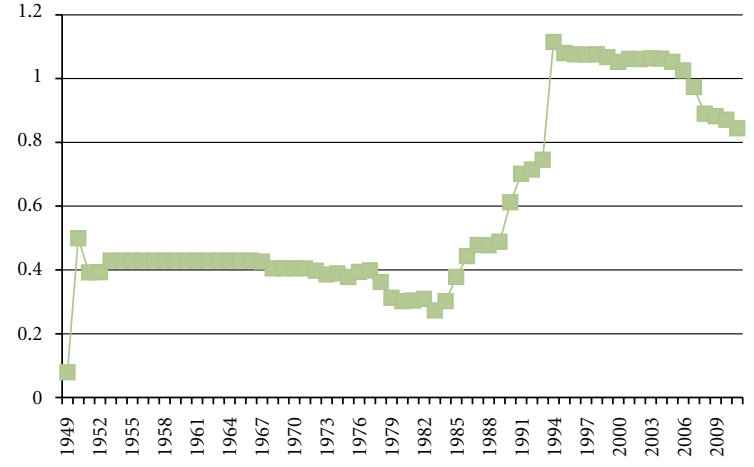

FIGURE 2: 1 HK\$ to RMB official exchange rate, 1949-2010.

To be sure, portentous signs of politically induced foreign investor amenability to, if not espousal of, the RMB as imminent global reserve currency may already be found beyond money markets, particularly in countries reliant on trade with China: Andrew Forrest, CEO of Australian mining stalwart Fortescue Metals, has recently declared, for example, that his company was "...now exploring the possibilities of being paid in Renminbi, purchasing equipment in Renminbi from our Renminbi bank accounts and bringing equipment into Australia and every other type of variety." Forrest's comments came a month after Rio Tinto, a BritishAustralian multinational mining and resources group with headquarters in London and Melbourne, had indicated it was considering settling iron ore sales in Renminbi because of pressure from Beijing to do so. But, in contrast to Fortescue Metals, Rio Tinto had no initial plans to start trading in Renminbi to offset its US\$ transactions [57].

The PRC has been slowly bowing to international pressure to revalue its currency along a narrow band as a means of reducing its trade surplus with the West. In 1994 US\$ 1 was worth RMB 8.6, but the rate dropped to 6.76 by 2010 (see Figure 1). Arguably, the greater adjustability of the RMB exchange rate achieved prior to 2008 was one of the factors, which helped China weather the Global Financial Crisis more effectively than the West. That said, many critics of the PRC suggest that this adjustment is too slow to assist recovery from the Global Financial Crisis of 2008 and that in the main it reflects the dollar's weakening against other foreign currencies rather than a genuine worsening in Chinese terms of trade (for comparison, see Figures 2 and 3) [58].

Sources for Figures 1-3. Data for 1949 were compiled from the study by Li Dongrong [59].

Data for 1950-1978 compiled in the main from Geguo huobi huijia tongji shouce [60].

Data for 1979 to the present were mainly compiled from the State Administration for Foreign Exchange website: http://www.safe.gov.cn/model_safe/tjsj/rmb_list.jsp?id=5\&ID $=110200000000000000$.

Notes for Figures 1-3. The Japanese Yen was floated against the US\$ in 1971. Prior to that, the Yen had been pegged to the dollar in line with the Bretton Woods accords at 360:1.

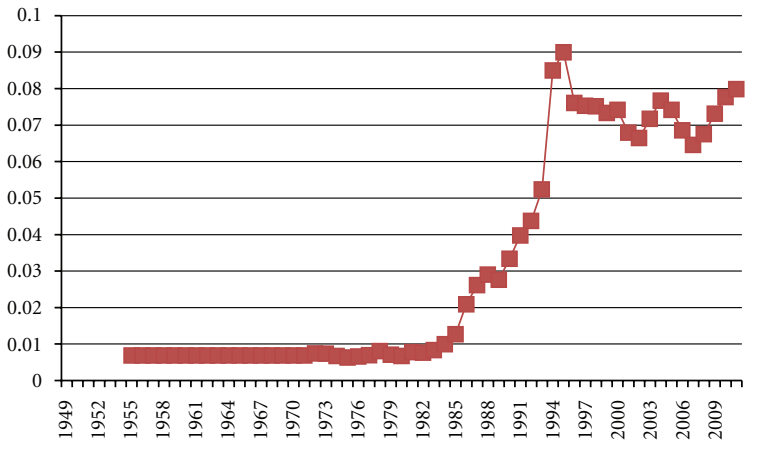

FIgURE 3: 1 Yen to RMB official exchange rate, 1949-2010.

The figures are corrected for the 1955 issuance of new RMB denominations at a rate of 1 to 10,000 old RMB. In 1983 the British colonial authorities in Hong Kong pledged to peg the $\mathrm{HK} \$$ to the US\$ at a rate of $7.8: 1$.

In the second decade of the 21st century, the notion of China eventually becoming a dominant economy is seldom disputed; neither is the notion that China has been one of the most salient beneficiaries of post-1989 globalization (for an integrative discussion of globalization and China's changing political economy, see $[61,62])$. Its growing clout on the world stage is reflected geopolitically in important multilateral organisations such as the WTO and the G20. By now, there seems to be growing recognition on the part of China's leaders of the potential benefits of greater RMB convertibility. Though China faces numerous economic challenges domestically, not least of which are environmental degradation and growing income disparity, there are signs of newfound confidence in China's economic growth model to allow for further internationalization of the RMB. As indicated above, RMB-denominated bonds have been issued in Hong Kong by PRC state-controlled banks and conglomerates since 2007 ("dim sum bonds"). In recent years, they have been joined by foreign conglomerates with large PRC operations such as McDonald's and Caterpillar. In January 2011, even the World Bank issued a series of "dim sum" bonds in Hong Kong. Within China, too, a select few multinational NGOs and banks were allowed in recent years to borrow funds on a trial basis from the Chinese public through the floatation of bonds in the domestic market ("panda bonds"): these include the IFC, the Asian Development Bank, and more recently, the Bank of Tokyo-Mitsubishi UFJ [54].

Moreover, experimental payment of RMB for some import goods from Southeast Asia has begun-this would have been unthinkable in the 1990s when it was illegal to take $\mathrm{RMB}$ out of the country. It may not be long before the RMB begins to play a significant role as an asset in other countries' sovereign funds and to consolidate its appeal on the crossrates as a result of both trade-related activity and broader financial demands. In the intermediate term, therefore, the pressure on the People's Bank of China to revalue the Renminbi looks set to mount (for official news coverage of this bond issue see, http://english.cntv.cn/20110614/103933 .shtml). 


\section{The Pros and Cons of Internationalising the RMB}

In PBC thinking there is currently a set of quantifiable and intangible advantages associated with potentially allowing the RMB to be freely tradable outside China. The primary quantifiable advantage would be, of course, the ability to enhance "seignorage" revenue in its abstract modern form (as opposed to the metallic seignorage of pre-modern times). In addition, RMB tradability is likely to increase the volume of international financial transactions to be cleared in China and thus hold out the prospect of more premium jobs created locally and greater financial services tax revenue. The main intangible advantage would, according to conventional wisdom, accrue to PRC citizens and firms rather than to the PRC government, whereby lower exchange commissions would have to be advanced when transacting business overseas. Yet the PRC government is likely to intangibly benefit from greater "soft power" if the RMB was internationalised [63]. In this context, it is important to consider some economists' estimates that the US derived a compounding windfall of US\$ 953 trillion between 1946 and 2002 purely as a result of the fact that the dollar was the main global reserve currency during that period. But the overall benefit to the US economy could have been manyfold bigger if intangible factors are factored in, according to a study by Chen et al. (The windfall was broken down to US\$ 678 trillion in seignorage-derived revenue and US\$ 274 trillion in financial benefits [63]).

Economists further suggest that, should the RMB become a regional reserve currency in East and Southeast Asia over the next decade, the Chinese economy could rake in a windfall of RMB 744 trillion, not to mention the impact on China's geostrategic clout in multilateral organisations such as the WTO and G20 [63]. The most obvious downside to RMB internationalisation is associated in PBC thinking with the potential weakening of macroeconomic levers that have so far stimulated Chinese exports, for example, the managedband exchange rate regime. Internationalisation would also pose the risk of Chinese nationals transferring assets overseas on short notice and allow for "hot money" to more easily penetrate the domestic economy and aggravate the already acute property bubble across much of the county's eastern seaboard [64].

Clearly, China's financial market is not sufficiently open at present to allow comprehensive RMB internationalisation. Notably, PRC nationals and firms still cannot independently purchase financial assets denominated in foreign currency. They are only able to invest in RMB in a select number of government-accredited foreign financial institutions or buy foreign securities only via a select number of state-controlled financial institutions. There is also lack of sufficient competition in the domestic financial market, with state-owned banks still accounting for the lion's share of retail loans and credit. China's own securities market only dates back to 1990 and is still not easily accessible to SMEs; credit is therefore skewed in favour of state-controlled large companies, often resulting in low returns to investment and misallocation of resources [65].
But many of the other preconditions for internationalisation have largely been met: China already accounts for large share of the world economy and has until recently been able to overcome inflationary pressures for the most part. Whilst capital-account movements across the border are still restricted, greater current-account convertibility is now permitted. In the face of financial market shortfalls, policy makers have of late gingerly moved to bestow on the RMB more international exposure. In June 2007 the first batch of RMB-denominated PRC bonds was floated in Hong Kong; in the following month the PBC set up a specialised Exchange Rates Department (huilüsi) with a mandate to promote the RMB's internationalisation as well as to enhance its prestige overseas. Furthermore, in March 2010, the State Council approved an experimental global RMB clearing centre in Hong Kong which is to be extended onto 20 Mainland regional centres in the near future. Indeed, in October 2010, the 12th PRC Five-Year Plan reaffirmed that Hong Kong is to become a test ground for clearing global RMB-denominated transactions. Then, on June 1, 2011, the PRC government announced a new experimental scheme whereby accredited institutions and individuals without domestic representation would be allowed to directly purchase RMB overseas. Evidently, then, important initial strides toward RMB's full convertibility have been completed over the last 3 years without any major shock recorded on the cross-rates (the wording of the June announcement can be viewed at, http://www.pbc .gov.cn/publish/huobizhengceersi/3131/index.html).

Notwithstanding the seemingly slow pace of reform in China's domestic equity markets and the limited recourse nonstate firms have thereto, Chen and Cheung contend that nonresidents currently own PRC equities equivalent to 24 per cent of the country's GDP, while nonresidents of Japan own domestic equities amounting to only 17 per cent of Japan's GDP. This factor, amongst others, seems to lead them to predict that more RMB-denominated bond issues and greater overseas trade volumes would of themselves turn the $\mathrm{RMB}$ into a global currency in the not-too-distant future) [54]. Moreover, Chen and Cheung report that the cumulative volume of nonfinancial trade settled in $\mathrm{RMB}$ increased from less than RMB 4 billion at the end of 2009 to RMB 290 billion by November 2010 Similarly, RMB-denominated bank deposits in Hong Kong have experienced an annualised growth rate of $450 \%$ in recent months. Currently making up around $5 \%$ of the total volume of Hong Kong bank deposits, RMB-denominated deposits may well come close, within a few years, to the $30.8 \%$ share which US\$-denominated bank deposits hold in the former Crown Colony [54].

\section{The Debate among Western and Japanese Scholars}

In his classic 1960 study, Robert Triffin suggested that the US\$ became international reserve currency sometime after World War II, namely, more than half a century after the US became the largest economy in the world [66]. But in their more recent important study Eichengreen and Flandreau analysed the makeup of international reserves in the interwar period, and found that the US\$ had actually overtaken 
the pound sterling to become the leading reserve currency as early as the 1920s. During the subsequent decade, despite short-term global currency tribulations arising as a result of US\$ devaluations, the US\$ became all but indispensable to international trade [67].

Against the backdrop of progressive dollar devaluations and what hitherto seemed like well-functioning European Monetary Union, Eichengreen and Flandreau concluded that the global monetary system could be re-made over a relatively short period of time; they even alluded to the fact that the Euro might well be on its way to unseating the greenback as preferred reserve currency. Perhaps more germane to the issue under review, Eichengreen and Flandreau also suggested that network effects and the advantages of incumbency should not be overestimated when weighing up the possibility of an emerging global currency "dethroning" a more established global currency [67].

Historic experience and economic theory suggest that in order to become global reserve currency a few preconditions need to be met simultaneously: the home economy of this currency needs to demonstrate stability and low inflation; the volume of the home economy should be the largest in the world; the home country must possess mature and solvent financial system [68]. The US has been the largest economy in the world throughout the 20th century and maintained low inflation during that period. At the same time, the US financial system was the most elaborate and invasive as measured, for example, in the ratio of publicly listed equity to GDP. It was the sheer scope and transparency of the New York money market that helped entrench the greenback as global reserve currency [59].

That said, the domestic subprime crisis of late 2007 which quickly deteriorated into the Global Financial Crisis of 2008 had stemmed from regulatory flaws in the very same financial system. The Crisis revealed deep structural distortions in the US economy like overconsumption, mammoth government deficit, and excessive risk incentives to corporate executives - these have cast doubts on the dollar as single viable reserve currency not least among Asian central banks. But talk of the RMB eventually supplanting the dollar in the financial press may not have necessarily emerged as a result. Rather, what triggered speculation of imminent RMB internationalization was the bleak forecast for economic performance in other parts of the developed world: crises in Spain, Ireland and Greece weigh heavily on the prospects of the Euro complementing the greenback as a more serious reserve currency, whilst the viability of the Japanese Yenonce mooted to supplant the greenback-has been tarnished since Japan's "Lost Decade" of the 1990s.

As a rapidly industrialising economy, which has posted double-digit annual growth rates over the past three decades, China quite obviously draws more global attention. It would appear that the RMB came to the fore as a future alternative to the greenback mainly as a result of the fact that China's banks performed much better than Western ones through the Global Financial Crisis. Until not long ago prominent economist such as Nicholas Lardy had identified China's banking system as the weakest link in its development model [42]. Yet the fact that-contrary to Europe and the US-no major bank bail-outs were reported in China; that a growth rate of over 9\% was still achieved between 2008 and 2009, and that China has now overtaken Japan as the world's second largest economy may well have psychologically primed Western public opinion to consider more seriously what appears to be a long-term historic shift of power from West to East.

Takatoshi Ito has argued that the PRC economy has proven so resilient because it has benefitted from underlying demographic dividend. Based on UN demographic statistics, Ito came to the conclusion that China would become the largest economy in the world no later than 2027. Apart from endogenous factors, Ito believes that the Global Financial Crisis provides the Chinese economy with a golden opportunity to stamp its mark geostrategically [69]. As the US is coming to the realisation that the financial market deregulation it has espoused as part of the so-called "Washington Consensus," as well as the very neoclassical theory that consensus is underpinned by, irreparably tarnished Wall Street's reputation, more and more commentators are betting on the alternative "Beijing Consensus" as an engine of growth in emerging markets precisely because of its more cautious approach to economic theory and market deregulation $[70,71]$.

\section{What Do Chinese Economists Think?}

Zhou Xiaochuan, the PBC Governor, has on a number of occasions stated his view that the RMB need not supplant the greenback as global reserve currency. Rather, Zhou supports the creation of a new composite international currency along the lines of the SDR-one that cannot be controlled by a single sovereign state and that would transcend narrow national agendas by factoring in the price of commodities such as gold. Nonetheless, a PBC study group set up by Zhou found that in the intermediate term it might be desirable for China to enhance the role which RMB plays in trade with neighbouring Asian countries as part of an emerging regional trade bloc, whereas today much of that intra-Asian trade is carried out in US\$ even though US firms are scarcely involved therein. Such a regional experiment could help coordinate RMB overseas exposure and help gain experience in averting currency instability in the future [72].

Within Chinese academe one can find a wider range of views. Economists are divided on the question of whether RMB internationalisation is desirable, and if so, at what pace. Li Daokui of Tsinghua University_-arguably the academic whose views have proven most influential in this debateis in favour of a stalling tactic whereby China would achieve free capital-account convertibility over a long period of time. Li et al. advocate a two-track gradualist approach: domestically, he sees no need to immediately allow full RMB convertibility and instead emphasises the need to improve the efficacy of China's financial system; on the other hand, Li et al. support a more rapid expansion of trade in RMBdenominated assets in Honk Kong with more PRC bond issues there and eventually the setting up of a second Hong Kong bourse exclusively dedicated to trade in RMB-denominated equity [73]. 
Prominent Hong Kong-born economist Steven NgSheong Cheung (known in China as Zhang Wuchang) has for many years opposed any revaluation of the RMB believing that it would only benefit a small coterie of wealthy PRC nationals who frequently travel overseas. China's most vulnerable population-rural migrants seeking employment in labour-intensive factories-would according to this theory be hard hit should foreign investors opt to relocate production lines to other countries as a result of RMB appreciation. In Cheung's typically conservative assessment, exchange rate predictability should firmly remain the anchorage of China's developing economy, whilst domestic market forces should perhaps be allowed to play a greater role in PBC interest-rate mechanisms. In contrast to Zhou Xiaochuan, Cheung does not believe in promoting a new composite global currency because the value of such a currency might be swayed by the volatile price of alternative global assets like gold. Instead of the current US\$ peg, Cheung proposes-against the backdrop of rising US indebtedness - to affix the value of the RMB to a basket of 30 foreign currencies and perishable goods, whilst providing the rural poor with a range of subsidies to alleviate the negative impact of a likely RMB appreciation $[43,44]$.

Larry Hsien-Ping Lang (Lang Xianping), a business scholar known for his outspoken opposition to State-Owned Enterprise reform, weighed into the RMB debate from the opposite direction. Lang pointed out that the problem with likely $\mathrm{RMB}$ appreciation as a result of internationalisation emanates from the current structure of the Chinese economy, which is fixed-investment driven and export-led rather than consumption and services based as in developed countries. Prior to RMB internationalisation, Lang argues that China would have to combat its inadequate domestic consumption rate by laying more social-security nets that would encourage the middle and lower classes to save less of their income. In the short term, however, Lang believes that the RMB is too devalued at present because it does not sufficiently factor in US-induced inflation: while this might seemingly promote employment in China's industrial export sector, the positive effect is outweighed by higher imported food staples (e.g., soy) and commodity prices (e.g., oil and iron ore). These in turn put upward pressure on the price of domestic goods, with a net outcome of making the poor even poorer, constraining consumption, and endearing industrial inputs [74].

Prominent neoliberal economist Chen Zhiwu, now based at Yale University, shares by and large Lang's observations. In Chen's view, the RMB's excessively slow appreciation against the US\$ is accentuating structural imbalances in China's economy, not least of which is loss of government control over the general price level particularly in the property and equity markets. Conversely, China's foreign reserves keep piling up, and hot money pours into the country fuelling a speculative boom that is hurting the country's strategic reliability overseas. Foreign speculators are attracted to China in part because the appreciation pace of the RMB has been made so predictable by government policy over the last decade. Furthermore, according to Chen the overly devalued $\mathrm{RMB}$ is stalling the much needed transition of Chinese industry to more sophisticated, capital-intensive products, whilst suppressing income in the bottom percentiles of the social-economic ladder [75].

Returning to the other end on the spectrum of views, the Senior Vice President of the World Bank, Lin Yifu, has recently warned that, in view of the slow pace of US economic recovery, any further revaluation of the RMB will immediately dampen consumption of Chinese goods in the US. Because most of these goods are not readily produced within the US, this will result in a further blow to net consumption in the US, setting back the recovery. In the longer run, Lin does recognise the need to increase Chinese domestic consumption but adds that a more important means of achieving balanced bilateral trade would be for the US to trim its government deficit. For Lin therefore stability in China is critical to world economic recovery at present, and any experimentation with market forces could jeopardise these aims [76].

\section{Conclusions}

Amid an emerging debate in the West about the prospects of other currencies or precious metals supplanting the US\$ as leading global reserve, this paper has sought to draw insights from the past in an effort to contextualise China's historic role in international currency provision over the longue durée. It has shown that, strictly speaking, there was no truly global currency before the discovery of rich silver deposits in Latin America and the spread of the SpanishAmerican silver dollar in the 17 th century.

Nonetheless, well before the discovery of the New World, traditional Chinese copper "cash" had served as a model for Japan and Korea's first indigenous currencies. Copper "cash" was also sought after in many parts of Southeast Asia, where previously South-Indian-modelled gold and silver currency had been in use. Notably, in the mid-12th century, Japan imported large amounts of Chinese copper coins, even though it was more copper abundant than China, and not bereft of metallurgic knowhow. Invented in China as early as the 11th century yet largely phased out by the 14th century, banknotes came into use in Europe only in the 17th century and spread continuously thereafter. It is arguably this temporal divide which might help explain the varying degree to which Chinese emperors and European monarchs aimed at enhancing seignorage revenue.

The current preoccupation with RMB as future international currency is not entirely devoid of the historic context of Chinese financial evolution. For even though traditionally cast Chinese copper coinage gave way to Western steampowered minting technology in the late 19th century, it had for a millennium or so prior set the benchmark for East and Southeast Asian monetization. Even as China was phasing out traditional copper coinage, Chinese indentured labourers were still taking it with them aboard British ships sailing across the South Pacific to serve as community currency for gambling and grocery purposes.

Today, of course, any global role which China's currency might play on the world stage would be divorced of the 
metallic anchorage which typified the monetary development stage prior to 1971. That year, following the breakdown of the Bretton Woods accords, most currencies of the world were beginning to slough off their linkage with gold, thereby circulating as media of exchange purely by state fiat. It would be careless to compare the pre-modern and current phases in the evolution of China's currency without recognising this ponderous difference. Yet, by the same token, one can still find resonances across starkly different eras in that quite often in history financial assets flowed into China from the West to offset surplus Chinese exports.

Faced with a rapidly growing Chinese economy, many pundits are forecasting that the RMB would soon become the world's reserve currency in lieu of the US\$. Such predictions are devoid of a historic context for the most part, and nor are these essential in arguing the case. Others contend that the deficiencies of China's financial market would continue to preclude any such transformation for a long time to come. This paper surveyed the arguments put forward by either camp, and weighed into this debate not only through the prism political economy but also through the prism of economic history. Chinese economists are mostly in favour of RMB gradual revaluation, arguing that it would be a boon to Chinese consumers, but some warn that a rapid appreciation could risk global recovery. The prevalent view as well as new policy measures suggest that, short of imminently floating the RMB, a further revaluation is highly likely.

If and how soon the RMB might supplant the greenback as global reserve currency is much harder to predict. Although RMB floatation is likely to benefit the Chinese economy in the long run, it is for now mainly advocated by economists associated with neoliberal views. At the policy-making echelons, figures like PBC Governor Zhou Xiaochuan disapprove of overt challenge to the US\$. Instead, they ultimately see the RMB as one of many monetary and commodity complements to the US\$ in establishing a new global standard. In the broader scheme of things, therefore, the extent to which the RMB would go global in the near future may not be determined solely by domestic financial and equity-market reform moves but, more importantly, by the overall geostrategic posture which China opts to embrace vis-à-vis the IMF, the World Bank and the G20; by the development model China implements and the shade of hegemony it chooses to exercises, as a resurgent superpower.

\section{References}

[1] F. Wu, R. Pan, and D. Wang, "Renminbi's potential to become a global currency," China and World Economy, vol. 18, no. 1, pp. 63-81, 2010.

[2] C. Hefeker and A. Nabor, "China's role in East-Asian monetary integration," International Journal of Finance and Economics, vol. 10, no. 2, pp. 157-166, 2005.

[3] N. A. Ritchie and S. Park, "Chinese coins down under: their role on the New Zealand goldfields," Australian Historical Archeology, vol. 5, pp. 41-48, 1987.

[4] L. Von Mises, The Theory of Money and Credit, The Liberty Fund, Indianapolis, Ind, USA, Translated by H. E. Batson, Reprinted 1982, 1912.
[5] J. Cribb, "Chinese coin finds from Arabia and the Arabian Gulf," Arabian Archaeology and Epigraphy, vol. 7, pp. 108-118, 1996.

[6] J. Lucassen, "Introduction," in Wages and Currency: Global Comparisons from Antiquity to the Twentieth Century, J. Lucassen, Ed., pp. 9-58, Peter Lang, Berlin, Germany, 2007.

[7] R. Sewell, Roman Coins Found in India, Royal Asiatic Society of Great Britain, London, UK, 1904.

[8] S. Whitfield, The Silk Road, Serindia Publications, Chicago, Ill, USA, 2004.

[9] S. E. Sidebotham, Roman Economic Policy in the ErythraThalassa, 30 B.C.-A.D. 217, Brill, Leiden, The Netherlands, 1986.

[10] P. J. Turner, Roman Coins from India, Royal Numismatic Society, London, UK, 1989.

[11] A. Wink, Al-Hind: Early Medieval India and the Expansion of Islam, 7th-11th Centuries, Brill, Leiden, The Netherlands, 2002.

[12] T. Higuchi, "Silk road: a culture of imported goods," Senri Ethnological Studies, vol. 32, pp. 33-36, 1992.

[13] A. Van Aelst, "A South-Chinese currency zone between the twelfth and nineteenth centuries," in Wages and Currency: Global Comparisons from Antiquity to the Twentieth Century, J. Lucassen, Ed., pp. 97-112, Peter Lang, Bern, Switzerland, 2007.

[14] A. Ghosh, Encyclopaedia of Indian Archaeology, Brill, New Delhi, India, 1989.

[15] H. W. Codrington, Ceylon Coins and Currency, Colombo Museum, Colombo, Sri Lanka, 1975.

[16] M. G. Raschke, "New studies in Roman commerce with the East," in Aufstieg und Niedergang der Römischen Welt, W. De Gruter, Ed., vol. 17, part 2, pp. 604-1278, Haase, Berlin, Germany, 1981.

[17] P. Greste, "Could a rusty coin re-write chinese-african history?" BBC, 2010, http://www.bbc.co.uk/news/world/africa/.

[18] M. Miyamoto and S. Shikano, "The emergence of the Tokugawa monetary system in East Asian international perspective," in Global Connections and Monetary History, 1470-1800, V. Glahn, A. Giraldez, and D. O. Flynn, Eds., pp. 169-186, Ashgate, Farnham, UK, 2003.

[19] Kim Chun-Gil and Kim Djun-Kil, The History of Korea, Greenwood, Westport, Conn, USA, 2005.

[20] J. Lee, "State-regulated industry in Qing China, The Yunnan mining industry: a regional economic cycle, 1700-1850," in Proceedings of the Conference on Spatial and Temporal Trends and Cycles in Chinese Economic History 980-1980, Las Vegas, NV, USA, 1984, Unpublished paper, sponsored by the ACLS and SSRC.

[21] A. Reid, Southeast Asia in the Early Modern Era: Trade, Power, and Belief, Cornell University Press, Ithaca, NY, USA, 1993.

[22] D. O. Flynn and A. Giráldez, "Born with a "silver spoon": the origin of world trade in 1571," Journal of World History, vol. 6, no. 2, pp. 201-221, 1995.

[23] N. Horesh, "Silk, tea, and treasure: maritime trade in eighteenth-century literature," Sungkyun Journal of East Asian Studies, vol. 8, no. 2, pp. 131-142, 2008.

[24] Timothy Brook, The Confusions of Pleasure: Commerce and Culture in Ming China, University of California Press, Berkeley, Calif, USA, 1999.

[25] W. Rowe, "Provincial monetary practice in eighteenth-century China: Chen Hongmou in Jiangxi and Shaan," in Chinese Handicraft Regulations of the Qing Dynasty, M. Murata, C. S. Jianze, and H. U. Vogel, Eds., Iudicium, Munich, Germany, 2005. 
[26] R. Von Glahn, Fountain of Fortune: Money and Monetary Policy in China 1000-1700, University of California Press, Berkeley, Calif, USA, 1996.

[27] H. U. Vogel, "Chinese central monetary policy and Yunnan copper mining in the early Qing," Late Imperial China, vol. 8, no. 2, pp. 1-52, 1983.

[28] History of Japanese Mining before the Meiji Era, Hatsubaijo Inoue Shoten, Tokyo, Japan, 1982.

[29] N. Horesh, "The transition from coinage to paper money in China: hallmarks of statehood in global perspective, 8th century BC to 1935 AD," Journal of the Institute of Asian Studies, vol. 21, no. 2, pp. 1-26, 2004.

[30] M. Weber, The Theory of Social Economic Organization, Free Press, New York, NY. USA, 1964.

[31] Akinobu Kuroda, "Another monetary economy: the case of traditional China," in Asia Pacific Dynamism 1550 - 2000, A. J. H. Latham and H. Kawakatsu, Eds., pp. 187-198, Routledge, London, UK, 2000.

[32] R. Von Glahn, in Fountain of Fortune: Money and Monetary Policy in China 1000-1700, p. 145, University of California Press, Berkeley, Calif, USA, 1996.

[33] J. H. Munro, "Billon: from byullion to base coinage," Revue Belge de Philology et D’histoire, vol. 52, no. 2, pp. 293-305, 1974.

[34] A. Kuroda, "The Eurasian silver century, 1276-1359: commensurability and multiplicity," Journal of Global History, vol. 4, no. 2, pp. 245-269, 2009.

[35] N. Horesh, Shanghai's Bund and Beyond: British Banks, Banknote Issuance and Monetary Policy in China, 1842-1937, Yale University Press, New Haven, Conn, USA, 2009.

[36] Richard Burdekin, China's Monetary Challenges: Past Experiences and Future Prospects, Cambridge University Press, New York, NY, USA, 2008.

[37] A. Schottenhammer, "The role of metals and the impact of the introduction of Huizi paper notes in Quanzhou on the development of maritime trade in the Song period," in The Emporium of the World, Maritime Quanzhou 1000-1400, A. Schottenhammer, Ed., pp. 95-176, Brill, Leiden, The Netherlands, 2001.

[38] L. Shi, Concise History of the RMB, Zhongguo jinrong chubanshe, Beijing, China, 1998.

[39] Mingyuan Chen, Witness to History: 40 Years' History of Coupons and $R M B$, Fenghuang chubanshe, Nanjing, China, 2009.

[40] Zhongguo yinhang hangshi, History of the Bank of China, Zhongguo jinrong chubanshe, Beijing, China, Comp. by the Bank of China, 1995.

[41] B. Naughton, Growing out of the Plan: Chinese Economic Reform, 1978-1993, Cambridge University Press, New York, NY, USA, 1996.

[42] N. R. Lardy, China's Unfinished Economic Revolution, Brookings Institution Press, Washington, DC, USA, 1998.

[43] J. Zhang, Banking Sector Reform and the Internationalization of RMB: History, Theory, and Policy, Zhongguo renmindaxue chubanshe, Beijing, China, 2010.

[44] W. Zhang, "The RMB must have some kind of a peg," Shangiie pinglun, vol. 9, p. 98, 2010.

[45] K. Kotani, Japanese Intelligence in World War II, Osprey, Oxford, UK, 2009.

[46] Y.-H. Hung, “A great victory for Mao Tse-Tung's thought on the financial and monetary front-China's People's currency has become an exceptionally stable currency of the world," Chinese Economy, vol. 3, no. 3, pp. 179-190, 1970.
[47] P. Li and Q. Yang, The RMB Exchange Rate: Theory, History, Reality and Development Trends, Jingji kexue chubanshe, Beijing, China, 1999.

[48] W. Tseng, Economic Reform in China: A New Phase, International Monetary Fund, Washington, DC, USA, 1994.

[49] L. L. Drumm, "Changing money: foreign exchange reform in the people's Republic of China," Hastings International \& Comparative Law Review, pp. 359-396, 1994-1995.

[50] G. Lin and R. M. Schramm, "China's foreign exchange policies since 1979: a review of developments and an assessment," China Economic Review, vol. 14, no. 3, pp. 246-280, 2003.

[51] L. H. Liew, "Policy elites in the political economy of China's exchange rate policymaking," Journal of Contemporary China, vol. 13, no. 1, pp. 21-51, 2002.

[52] Y. Long, Further Development of Renminbi's Exchange Rate Regime after Joining the WTO, Grin, Munich, Germany, 2011.

[53] E. Ogawa, "Should East Asian countries return to a dollar peg again?" in East Asian Trade and Financial Integration: New Issues, P. Drysdale and K. Ishigaki, Eds., pp. 159-184, Asia Pacific Press, 2002.

[54] Xiaoli Chen and Y.-W Cheung, "Renminbi going global," China \& World Economy, vol. 19, no. 2, pp. 1-18, 2011.

[55] L. Wei, "New move to make Yuan a global currency," Wall Street Journal, 2011, http://online.wsj.com/article/SB10001424 052748703791904576076082178393532.html.

[56] J. Shi, "Are currency appreciations contractionary in China," in International Financial Issues in the Pacific Rim: Global Imbalances, Financial Liberalization, and Exchange Rate Policy, I. Takatoshi and A. Rose, Eds., pp. 77-101, University of Chicago Press, Chicago, Ill, USA, 2008.

[57] M. Chambers, "It's Yuan for the money for twiggy forrest," The Australian, 2011, http://www.theaustralian.com.au/business/ mining-energy/its-yuan-for-the-money-for-twiggy-forrest/ story-e6frg9df-1226093397794/.

[58] Y. Le, "China's foreign exchange markets," in China's Financial Markets: An Insider's Guide to How the Markets Work, S. N. Neftci and M. Y. Ménager-Xu, Eds., pp. 112-134, Elsevier, New York, NY, USA, 2007.

[59] R. J. Carbaugh and D. W. Hedrick, "Will the dollar be dethroned as the main reserve currency?" Global Economy Journal, vol. 9, no. 3, article 1, 2009.

[60] Geguo huobi huijia tongji shouce, Foreign Exchange Rtaes by Country-A Statistical Handbook, Zhongguo caijingjingji chubanshe, Beijing, China, Comp. by the Bank of China, 1979.

[61] D. Zweig, Internationalizing China: Domestic Interests and Global Linkages, Cornell University Press, Ithaca, NY, USA, 2002.

[62] L. H. Liew, "Changing China's political economy: uniting and dividing impacts of globalisation," in Globalisation and the Asia-Pacific: Contested Perspectives and Diverse Experiences, 1. Islam and M. Hossain, Eds., pp. 131-149, Edward Elgar Publishing, Camberley, UK.

[63] Y. Chen, F. Wang, and M. Yang, "Internationalization of currency as a transnational competition strategy: evidential experience of the US dollar on the globalization of the renminbi," Economic Research, vol. 2, pp. 35-44, 2005.

[64] RMB Internationalization Study Group, "The timing, path and strategy of RMB internationalization," Zhongguo jinrong, vol. 5, pp. 12-13, 2006.

[65] W. Dobson and P. R. Masson, "Will the renminbi become a world currency?" China Economic Review, vol. 20, no. 1, pp. 124-135, 2009.

[66] R. Triffin, Gold and the Dollar Crisis-The Future of Convertibility, Yale University Press, New Haven, Conn, USA, 1960. 
[67] B. Eichengreen and M. Flandreau, "The rise and fall of the dollar, or when did the dollar replace sterling as the leading international currency?" NBER working paper number 14154, 2008.

[68] G. S. Tavlas, "On the international use of currencies: the case of the Deutsche Mark," International Monetary Fund working paper number 90/3, 1990.

[69] T. Ito, "China as number one: how about the Renminbi?" Asian Economic Policy Review, vol. 5, no. 2, pp. 249-276, 2010.

[70] J. W. Lee, "Comment on "China as number one: how about the renminbi?"', Asian Economic Policy Review, vol. 5, no. 2, pp. 277-278, 2010.

[71] S. Takagi, "Comment on "China as number one: how about the renminbi?"', Asian Economic Policy Review, vol. 5, no. 2, pp. 279-280, 2010.

[72] Xiaochuan Zhou, "Thoughts on reforming toward an international currency system," Zhongguo jinrong, vol. 7, pp. 8-9, 2009.

[73] D. Li and Linlin Liu, "RMB internationalization should be two-track," Zhongguo jinrong, vol. 10, pp. 42-43, 2008.

[74] Xianping Lang, "Will a revalued RMB make you richer?" Shiye, vol. 8, p. 40, 2009.

[75] Z. Chen, "Excess liquidity is aggravated by the extra-slow of appreciation of RMB," Caifu Luntan, vol. 3, pp. 129-130, 2008.

[76] Y. Lin, "RMB revaluation might kill off global recovery," Renmin Luntan Zhenglun Shuangzhoukan, vol. 22, p. 158, 2009. 


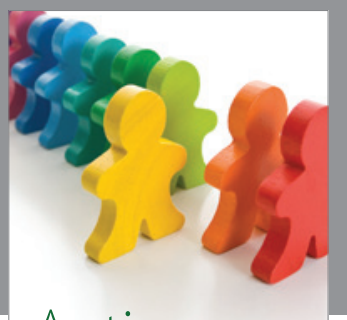

Autism

Research and Treatment
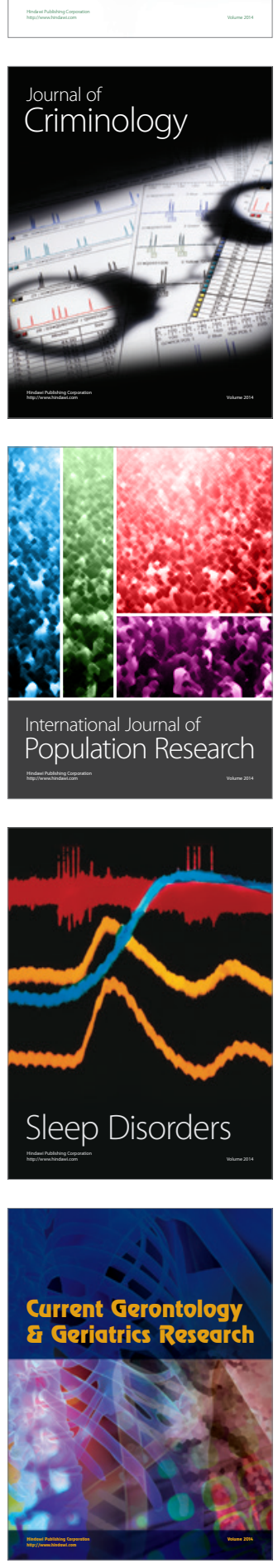
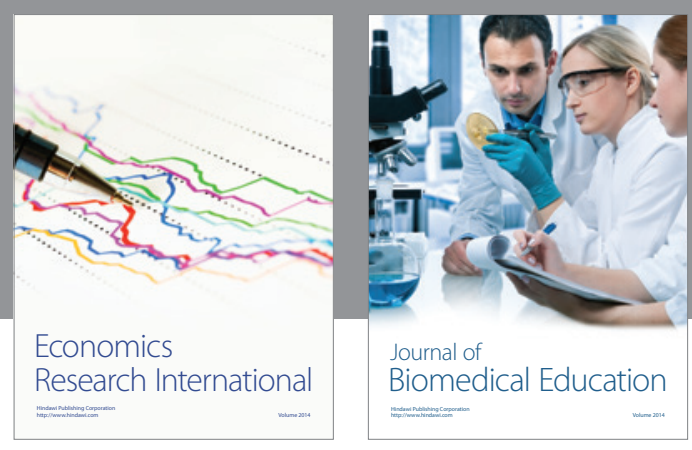

Journal of

Biomedical Education

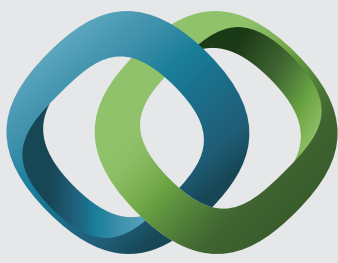

\section{Hindawi}

Submit your manuscripts at

http://www.hindawi.com
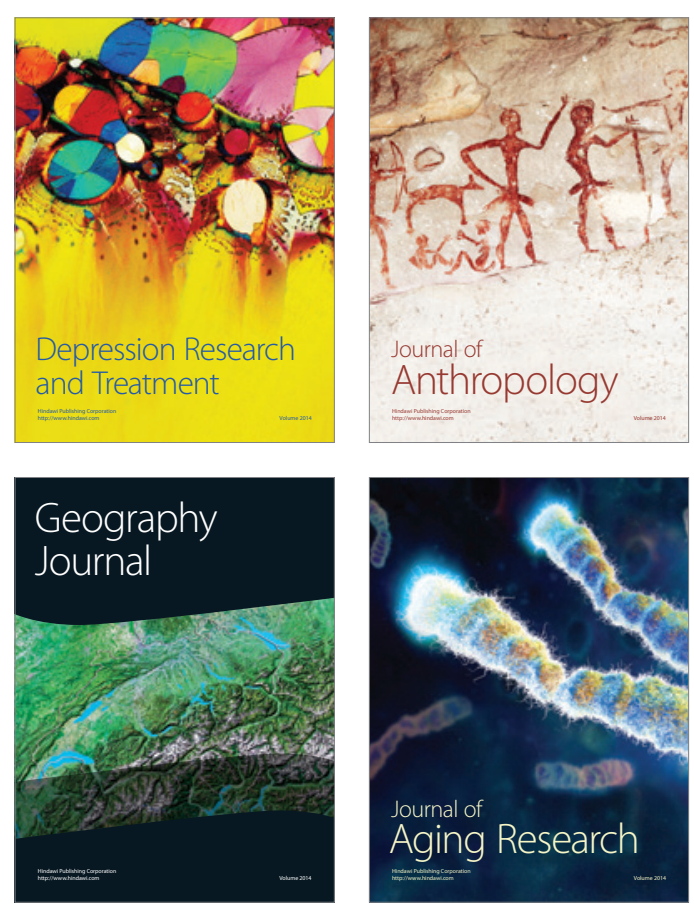

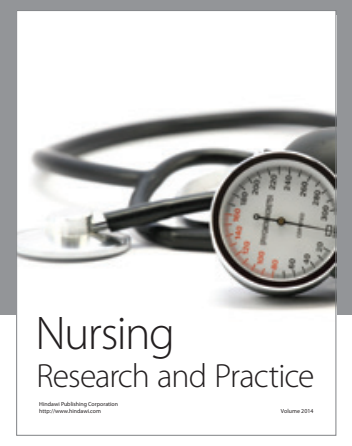

Nursing

Research and Practice

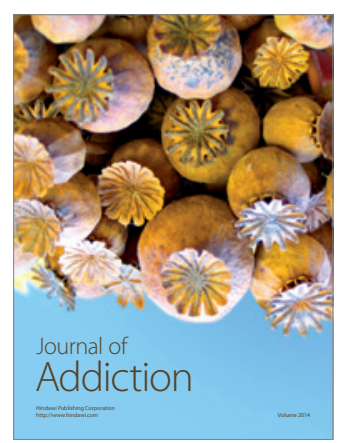

Child Development

Research

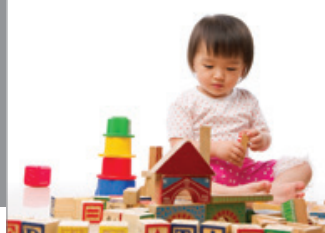

迥
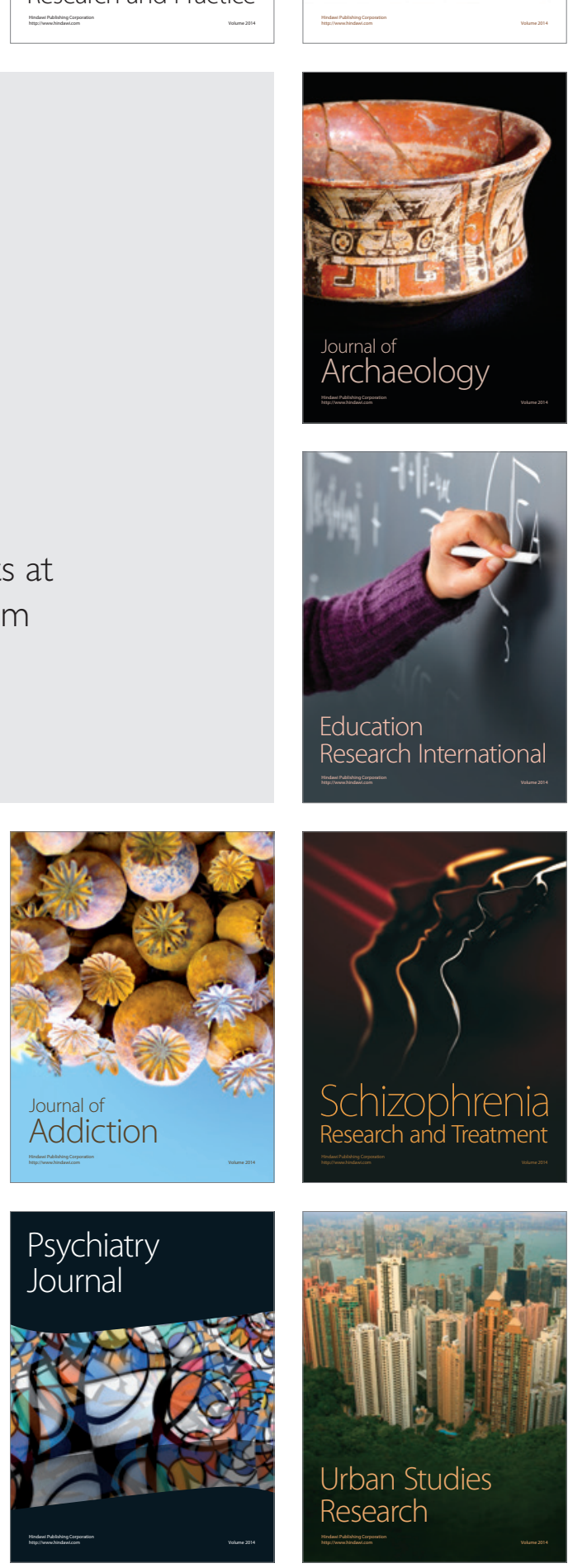